http://dx.doi.org/10.4314/gjl.v6i3.3

\title{
ASPECTS OF YORUBA LINGUAL-CULTURAL RETENTIONS IN ABIMBOLA ADELAKUN'S UNDER THE BROWN RUSTED ROOFS
}

\author{
Mohammed Ayodeji Ademilokun
}

\begin{abstract}
Previous studies on nativisation of English in African literary productions have focused on literary works of first and second generation African writers such as Amos Tutuola, Chinua Achebe, Niyi Osundare among others, with little critical attention paid to nativisation of English by new Nigerian writers. This essay adds to the discourse on the subject of language in African literature by examining the language of Abimbola Adunni Adelakun, a new generation Nigerian writer, in Under the Brown Rusted Roofs. Through a close reading of the text and insights from Systemic Functional Linguistics, this paper elucidates the various Yoruba lingualcultural features used by the new generation Nigerian writer for the promotion of Yoruba identity in the text. Data analysis revealed that Adelakun used lexical transfer, literal translation, coinages, code-mixing, proverbs, incantatory discourse, Yoruba Muslim discourse features, Yoruba advertising poetry and lineage praise poetry to nativise the literary text by giving it a Yoruba coloration. The study concludes that Adelakun's use of the English language further enhances the African identity and shows that new generation writers are also committed to linguistic nationalism in their prosecution of their literary enterprise.
\end{abstract}

Keywords: lingual-cultural, retentions, Abimbola Adelakun, nativisation, linguistic nationalism 


\section{Introduction}

All over the world, the issue of identity is taken seriously by people. The European Americans for instance consider themselves different from and in fact superior to Black Americans. Also in the United Kingdom, the people of Great Britain view themselves as different from the Irish, Scotts, etc. The African continent on its own has pressed aggressively to establish a comprehensive identity for itself in various spheres; cultural, economic, political, etc. The African experience in this regard has been particularly unique considering the fact that Africa as a continent has a completely subjugated past and history. Since the 1814 partition of Africa among the Western powers at the Berlin Conference, Africa has had its essence and history distorted and suppressed. Thus, upon the independence of the African states from their colonial rulers, especially between 1952 and 1960, it has been an uphill task for African nations to re-assert their identities. One domain in which Africans have striven hard to foreground African identity or identities is literature, especially written literature. There is indeed justification for the deployment of literature as a tool for re-assertion by Africans. Literature, as a field of knowledge, reflects and sheds light on every part of the life of a people. Adedoyin (2001:212) captures this succinctly by defining literature "as a bundle of materials, written and oral, which utilize language, plot, characters, settings, etc. to give and illustrate what actually the life of the people looks like". Therefore, since literature indexes everything about a people, it is a potent resource for expressing the peculiarities of such people. This exactly is the reality tapped into by African writers in their compositions.

\section{Language as a Tool for Identity Formation in African Writings}

The issue of which language is most appropriate for African literary writing has always been contentious. Nkosi (1981) confirms this reality when he asserts that "The problem of the medium of expression in African literature has been a major issue among the African intellectuals". Coker and Ademilokun (2013) affirm that the issue of language continues to be a much debated one even up to the present times. There are different strands of argument on the issue. While some believe that the English language, being the legacy left by the colonialists is the most appropriate medium for the expression of African literature, some believe that the continued use of the language is a further perpetuation of the cultural hegemony of the former colonial lords. Of course, the advocates of the former 
have their reasons. One major reason for the suggestion of English as a medium for African writing is that the language cuts across many African peoples unlike the indigenous languages that are mostly specific to certain ethnic groups or at most countries. Another potential reason over the years for the suggestion of English as tool for composition of African writings is the elitist status of the language. Very many people will want to opine that the international status of the language makes it the best option for African writing. Adedoyin (2001) informs that scholars and African writers who see nothing wrong with the use of English in African writing belong to the conservative school.

For those who oppose the adoption of English as medium of expression in African literature, the belief is that the use of the language will not in any way contribute to the development of the literature and culture. The opinion of this group of scholars is summed up in Wali's (1963:14) declaration that "any true African literature must be written in African languages". Several other African scholars and writers share Obi Wali's sentiments. In fact, a Kenyan writer and a great African voice, Ngũgĩ wa Thiong'o was vehement in his opposition to English as medium of expression in African literature, prompting him to adopt Kikuyu as his creative medium. Wole Soyinka at some point also shared the views of Wali and Ngũgĩ. He advocated for the adoption of Swahili as the language of African literature. Although till date, no African language has been chosen as the medium for African literature, what is evident is that African scholars and writers have always been mindful of the need to establish a unique identity for African writing.

The reality however is that foreign languages, especially English and French, persist as media of expression in African writings. Apart from Ngugi who wrote a few of his works in Kikuyu, most African writers, including Soyinka who expressed complete disinterest in the use of the foreign tongue in African literature, write in foreign languages. But does this status-quo mean that there are no retentions of Africanity in the language use of these writers/scholars? A great deal of studies has shown that even though African writers are constrained to write in foreign languages such as English and French, there are African linguistic and cultural preservations in their language use. In actual fact, Soyinka (1988) opines that since it is difficult to write African literature in indigenous languages, the English language must be tamed to reflect the smell and contours of the environment of its use. What Wole Soyinka advocates can thus be described as domestication or Africanization of the English language in African literary writing. Indeed, very many African writers have done well to Africanise the English language in their writings. Chinua Achebe for instance uses the English language in a way in which retentions of African linguistic and cultural tropes are kept. Wole Soyinka, Niyi Osundare and numerous others 
have continued to use the English language in a peculiar manner in African literature. Ayoola (2012: 195) attests to this reality in the following words:

With the international acclaim received by Nigerian-born authors such as Chinua Achebe, Flora Nwapa, Wole Soyinka, Buchi Emecheta, Cyprian Ekwensi, Chukwuemeka Ike, Naiwu Osahon, Elechi Amadi and many more, Nigerian (African) authors have continued to use English with uncommon innovativeness, style and panache (Word in italics mine).

However, as is evident from Ayoola (2012), Adedoyin (2001) among others, much of the research on domestication of English by African writers is skewed towards Nigerian literary icons of the first and second generations. Several studies have been carried out for instance on the language of Chinua Achebe (e.g. Adedoyin, 2001; Ayoola, 2012), showing that the author nativises the English language by using Igbo proverbs and idioms, local expressions, among many others. Also, scholars have examined the use of proverbs and Yoruba adages and parlances in Wole Soyinka's works (e.g. Adejare, 1992; Syal, 1991). Other iconic Nigerian writers whose nativised linguistic styles have received scholarly attention include Niyi Osundare (see Coker 2013), Gabriel Okara and Amos Tutuola.

However, not much attention has been given to how the tradition is sustained or perhaps improved upon in the writings of new-generation Nigerian writers. It is important to examine dimensions of domestication of English in new Nigerian writings to find out whether there are similarities or differences in the old and new styles of nativisation by veteran Nigerian writers and the young ones given the generational difference and the new realities in the world of the latter. Apart from Coker and Ademilokun (2013) and Ayeleru (2011), there is not much research on nativisation of English by new Nigerian writers. While Coker and Ademilokun (ibid) compared domestication of English in Shade Adeniran's Imagine This and Doreen Baigana's Tropical Fish, Ayeleru (ibid) did a comparative reading of Adelaide Fassinou and Abimbola Adunni's Under the Brown Rusted Roofs. This paper seeks to add to the literature in this regard by examining the language style of indigenisation in Abimbola Adelakun's Under the Brown Rusted Roofs. While it is acknowledged that Ayeleru examined some aspects of her nativisation of English in the text, the full range of domestication of English was not exhausted in the study due to its comparative orientation. Furthermore, the present study intends to add 
more linguistic dimensions to the analysis of Under the Brown Rusted Roofs. Nativisation of English in Adelakun's Under the Brown Rusted Roofs particularly deserves attention because of the synchrony of the language of the text with the nature of its theme, characters and to a great extent setting, which actually reflect traditional Yoruba life and living.

\section{Under the Brown Rusted Roof: A Synopsis}

Abimbola Adelakun tries to represent traditional Yoruba cultural practices and family in the text. The African tradition of polygamy which is popular in Yoruba culture receives attention in the text in a manner in which its pros and cons are presented to readers. The major characters in the text, Alhaji Arigbabuwo and Bàbá N'sàlè̀, typically represent the Yoruba ideals of polygamy and the patriarchal nature of the Yoruba world. Being set in Ibadan, a typical traditional Yoruba city, the text captures the politics of polygamy among the Yoruba and its pains. The politics manifests clearly in the intricacies implicit in the relationships among the various wives and their polygamous husbands, especially Alhaji Arigbabuwo. The text which is a narrative fiction draws on some aspects of Nigerian history as the plot relates to certain happenings in Nigeria at some stage of its development.

The language of the text clearly depicts the physical, cultural and psychological settings of the text, which is the city of Ibadan marked by prevalent polygamy, political volatility and relative poverty, especially in certain rustic parts such as the agboolés (extended family compounds) represented in the text. Owing to the dynamic interaction of the provincial and the metropolitan in Ibadan, which makes features of provincial language use manifest in urban settings in the town, the text clearly indexes a significant aspect of the linguistic nature of the town. The language bears vivid taints of Yoruba discourse patterns and mannerisms which are used to proudly by the writer to mark out the type of English language used by a significant number of the Yoruba of Ibadan.

\section{Analysis and Discussion}

Although Under the Brown Rusted Roofs is Abimbola Adelakun's debut novel, she exhibits great panache in nativising the English language used in the work. The language of the text presents the author as an unusual member of the young generation of writers in view of her deep awareness of Yoruba discourse features which she uses to colourise her text and give it indelible Yoruba identity. Adelakun exhibits profound grasp 
of the cadences of her indigenous language which she brings to bear in her use of English in creating her debut novel. Notable among the patterns of lingual-cultural colourisation evident in the text are lexical transfer, hybridisation, literal transliteration, Yoruba Muslim discourse patterns, coinages, code-switching, Yoruba incantatory discourse and Yoruba advertising poetry. Below, we explore the above-listed styles of nativisation of English deployed by Abimbola Adelakun in Under the Brown Rusted Roofs.

\subsection{Lexical Transfer}

One way by which Adelakun stamped Yoruba identity in her text is through the direct transfer of Yoruba words into the English language. Varga et al. (2011) remark that the transfer of foreign lexical items into a language, which can be called borrowing or loan words, simply echoes the view that "no language is an island" and that it arises as a result of contact between languages. Lexical transfer is a style that many African writers often use to nativise their English language in their literary productions owing to its practicality in preserving indigenous thoughts and ideations. Adelakun in consciousness of the fact that there are certain concepts and ideations in Yoruba lingual-cultural world which she captures in her text, which lack replication in the English language, intentionally used those Yoruba words to preserve their meanings. This can be seen as a conscious strategy used by the author to synchronise the language of the text with the ideological grounding of the text which is the celebration of typical Yoruba life in the historic Yoruba city of Ibadan. There are many examples of such lexical transfers in the text, some of which are:

- Ėèdè (11)

- agboolé(11)

- olórí burúkú(11)

- agbomolà (12)

- gàrí(14)

- ewédú (14)

- iyálé àgbà (17)

- agbádá (18)

- akòwé(25)

- àtùpà (30) 
- àbùlà (30)

- àmàlà (30)

- òsùká (33)

- òyinbó (35)

- iyálés (42)

- alálobò (44)

- iyá àgbà (45)

- àbíkús (50)

- oòrí(52)

The above words are all Yoruba words used by the writer to give a lucid Yoruba colour to the English used in the literary text. Although Adelakun might be understood to have used some of the words given the fact that they do not have any equivalences in the standard English, e.g., "agbádá", "òsùká", "gàrí”, "ewédú”, "alálobọ̀", and they may be difficult to translate to English, there are some that have English equivalents which she ignored. For example, "oòrí" is generally known as shea butter in most contexts of English language use just as "akọ̀wé" is generally acceptable to be given in English as "secretary". But Adelakun intentionally uses the Yoruba words even though she presents their English equivalents in appositive relationships with them, showing further that the use of the Yoruba words is intentional. The use of lexical transfer in the text can thus be seen as not only motivated by the need for preservation of meaning but also an expression of outright linguistic and cultural patriotism which is common among many African writers who believe that even though for political reasons English cannot be avoided, it should be laden with indigenous expressions and concepts.

\subsection{Literal Translation}

Perhaps the most prevalent style used by Adelakun to make the language of her novel reflect the indigenous language of the Yoruba depicted by the setting and characters of her work is literal translation. Literal translation is the direct conveyance of the meaning of an expression in a source language into its closest form in the target language bearing the features of language use in the target language. Barbe (1996:332) views literal translation simply as a word for word translation which however "can only rarely reproduce the sense or meaning" of the source or original text. This linguistic practice is conditioned by the sheer inability of many speakers to reconstruct their thoughts in their 
source language into the natural expressive patterns in the target language due to inadequate facility in the target language, possible unavailability of equivalents in the target language, stylistic choice and the sheer fact of cultural differences between the source language culture and the target language culture. The English language spoken by the characters in the text and the omniscient narrator smacks of direct translation from Yoruba to English. This strategy can be said to be a practical way by which the writer reflects the nature of the linguistic landscape of the setting of the text (the melding of the provincial and the metropolitan in the city) and the English language awareness level of the characters in the text, which reflects the linguistic community of lowly educated or uneducated people in traditional rural parts of Ibadan. Abimbola generously translates from Yoruba to English in her work, translating sentences, wise sayings, greetings, proverbs, among others. Examples of translated sentences in the text are:

- She had started using cream like her peers. (23)

- Today makes it exactly ten days since this seating sent me to Alhaji Chief Iyiola (27)

- I opened my mouth in surprise and I could not close it. (28)

- That was how I saw it o. (28)

- Who is your father in this Ibadan? (29)

- Don't hear him wrongly. (29)

- He and his mother sat in the falling darkness, talking about small things. (30)

- My life! (31)

- God will look down on us and make our lives too better (47)

- I was told your body is not good. (34)

- Thank you, your end will be good. (35)

The above listed sentences are normal or common Yoruba expressions translated into the English language. The expressions definitely do not conform to the standard English variants as they have been directly translated from Yoruba to English. For example, "She had started using cream" is from the Yoruba everyday expression "Ó ti bẹ̀rè sí lo o kriimu" while the next is "Ė ní ni ó pé ojọ́ kẹ̀wá tí ìjókò yi rán mí lọ sí Alhaji Iyiola". All the other examples also sound exactly the way they are produced in normal Yoruba discourse. It is significant that most of the expressions are produced directly by the characters in the text 
except "He and his mother sat in the falling darkness talking about small things", showing the nature of English language used in their setting, a typical rural Yoruba community. The exception which was produced by the authorial voice is also significant. It speaks about the sheer interest and involvement of the author in Yoruba culture and language, even though it might also have been a conscious stylistic choice intended to produce humour. There are also few Yoruba phatic expressions translated into English in the text:

- I greet this seating (26)

- This our seating will not be spoilt (36)

- May this meeting not break up (143)

- May the person coming in not break it up (143)

- Baba, may you live long for us and may your elderly status never be destroyed (230)

- I greet everybody (243)

The above expressions reflect an important aspect of Yoruba culture which Adelakun uses to give a vivid Yoruba colour to her language and work. Greeting is a fundamental aspect of Yoruba culture which is held sacrosanct, as it is considered inappropriate for individuals not to offer greetings properly in any physical contacts or communicative contexts. However, in presenting greetings in the literary work, Adelakun directly translates typical Yoruba greetings to English. The expression "I greet this seating" with the SPC structure conforms with the Yoruba source expression "Mo kí ijóko yí" which also has an SPC structure, even though the nominal group that occupies the complement position differs from that of English as it is typical of modifiers to occur after the headword in Yoruba. There are also many instances of direct translation of Yoruba proverbs into English in the work:

- It is yet with the mouth that the foot crushes the palm-kernel that lies on the footpath (Enu l'à tè lésè fi ń pa èkùro ojú ònà) (25)

- Where I am going is not far, it is the number of detours that I will make that are plenty. (Ibi tí mo ń lo ò jìnnà, ibi tí mo yà l'ó pò)

- ...where we call the head, nobody puts it on the ground and attempts to walk with it.... (ibi tí a bá pè l'órí, enikan i fi ibè tẹlẹ) (28)

- ...one that hears only a side of a matter and pronounces judgment is a worthless elder... (Eni tí ó bá gbọ́ òrò ẹnikan dájó, àgbà òṣikà ni) (29) 
- We will not say that because the child will die, we should give him his father's scrotum to play with ( $A$ à níl so pé nítori kí omo máa kú, kí a wá fún un ní êpòn bàbá ẹ láti fi ṣeré) (38)

- This is a matter that farts in one's mouth and also puts salt into the mouth at the same time (Òrò̀ yì yasó sí ni lẹnu, ó tún fiyò sí i lẹệkan náà) (38)

- It is when we use the right hand to wash the left, that our hands are thoroughly cleaned (Nígbà tí a bá fi owó òtún fo tòsì ni owó máa ń mó sáká) (39)

- There is no way that the monkey's head was shaped that the gorilla is not (Kò sí bi ôbo șe șe orí tí inàkí ò șe) (41)

- If you let your eyes look down, you will see your nose (Tí a bá de ojú, a máa rí imú) (45)

- To catch someone is to catch someone; to point someone out is to point someone out but what is greeting an Ijaye man in front of Ogunmola's house? (Amúni ń jé amúni; afinihàn ń jẹ afinihàn, èwo wáá ni kí a kí okùnrin İjàyè nílé Ògúnmọ́lá) (55)

The above listed proverbs are just a minute fraction of Yoruba proverbs translated into English by Abimbola Adelakun. The direct translation as shown by their presented Yoruba versions is a conscious ploy to give a full Yoruba colour to the proverbs even though they are used in an English literary discourse.

\subsection{Coinages}

Another significant feature of the nativised English of Adelakun is the use of coinages. According to Abdullahi-Idiagbon and Olaniyi (2011: 79), coinages or neologisms are identified as new terms created for new experiences, especially where the speaker of the new language either experiences dearth of correct standard lexical item to express himself or uses a word or an expression to satisfy the communicative purpose of his immediate environment". Therefore, coinages can be simply viewed as words or phrases used for the expression of new or different experiences. Below are examples of coinages in the text: 
- The most senior wife (17)

- Water pot (11)

- co-wive (86)

- 'andco'. (110)

The expressions above are all coinages which do not occur in Standard English as used for meaning-making in the literary text. The expressions are derived through the manipulation of existing English words to represent certain thoughts and concepts which do not exist in the English culture but which the author wishes to stretch the English language to accommodate without lexical transfer. For example, the $\mathrm{MH}$ nominal group "The most senior wife" represents a reality which British or American English does not cater for, since there is nothing like that in the culture. But since in the Yoruba and African cultures, there is the reality of someone being senior among a number of wives, the expressed is coined to reflect that reality. Similarly, the word "co-wife" is a coinage used to reflect the reality of polygamy common in Africa but which is not found in the culture that birthed standard English. The coinage is also a product of linguistic need as it expresses an African idea of the relationship between or among women that are married to the same man.

The MH-type nominal group, "Water pot" is also a peculiar Nigerian/Yoruba lexical innovation since the idea of keeping water in a clayey pot in order to make the water become relatively cold is African, without any resonance of it in in the English culture and British English. The last example of coinage given above, "andco", is intentionally used by the author to preserve the natural linguistic norm among the Yoruba people depicted in the literary text. Although the word may not be satisfactorily linguistically analysed as an English word, it is however generally used in both English and Yoruba conversations of the Yoruba of Nigeria. The writer could have used the English word "uniform" in its stead but decided not to perhaps due to the multiplicity of meaning in the latter.

\subsection{Code-mixing}

Adelakun also frequently deploys code-mixing in the literary text. According to Essien (1997: 271), code-mixing is the formation of an expression through linguistic items from two different languages. The omniscient narrator and characters in the literary text freely code-mix English and Yoruba. Of course, through this, one can say that Adelakun 
paints a picture of naturally-occurring language use among Yoruba speakers since they often typically code-mix for various reasons such as lack of adequate English equivalent for some Yoruba words, mental laziness and stylistic preference, among others. Below are instances of code-mixing in the novel:

- Fasila entered the ẹ̀èdè and stood there (12)

- Iya, I could not get the agbomolà leaf (13)

- You want to turn the child into an olóríburúkú (14)

- How can she beat you because oil from àkàrà stained your book? (23)

- Tell us why you are shedding tears like ebòlò vegetables (43)

- That evening, the olóbìnrin-ilé met once (59)

As can be seen from the examples above, Yoruba words are frequently inserted into English expressions and sentences in the novel. The most lucid for this stylistic decision by the author may not be unconnected with the difficulty or impossibility of finding English lexical equivalents for the words as in the cases of "agbomola", "ebolo" and "olobinrin-ile" in the examples above. Of course, there is also the intention of the author to mark Yoruba identity through the linguistic choice.

\subsection{Proverbs}

Proverbs are wise sayings that address the heart of discourse in any given context truthfully and objectively (Adedimeji, 2009). Coker and Coker (2008:49) state that "Yoruba proverbs are replete in philosophy and ethics". This explains the premium placed on proverbs among the Yoruba, as they are used to giving philosophical tones to important issues. Adelakun exhibits unusual candour in using Yoruba proverbs more unlike her generation of Yoruba speakers as she generously deploys Yoruba proverbs in her work. Apart from the examples of proverbs cited under translation, there are other numerous proverbs used by the writer:

- What's scalding your hands so much that you need to put it down... (62)

- ... if a person is crying, the person can still see (70)

- If the farm is not far, how can the okro become overripe (72) 
- If you don't want a long pointed stick to be driven into your eye, you start shouting about it from a distance (73)

- A matter cannot be so hard that we would use a knife to cut through it. (75)

- The wind has blown and we have seen the anus of the chicken (80)

- We cannot fear the vagina so much that we fuck it at the sides (82)

- Everything in this world may change but 'this is the way I will do my thing' does not change (91)

- When a child is cutting a tree in the forest, it is only an elder that knows which direction it would fall (110)

- The vagina says she can trust the penis in all things but it can never see her and look away (123)

The above listed proverbs are used to engage critical issues in the text and give a clear Yoruba colour to the work. For instance, the proverb on page 62 indicated above was used by Motara, Alhaji Arigbabuwo's first wife to scold Kudi, the mother to Mulika, who was impregnated by Motara's son, Rafiu. The proverb was used by Motara to interrogate why Kudi would violate the Yoruba principle of greeting first in any physical or communicative contact. Similarly, as other proverbs do, the proverb "When a child is cutting a tree in the forest, it is only an elder that knows which direction it would fall" is used to draw attention to the critical fact that the young cannot think, imagine and discern as much as the elderly. The proverb was actually used by Baba n' sale, who represents the most elderly male figure in the text.

While many of the proverbs are generally used to engage salient issues, some are also used to portray the Yoruba culture and people's tendency to engage in lewd talks. Many of the proverbs have sexual associations showing that the Yoruba are free to draw from sexual images in order to interrogate issues. For instance, the proverb "We cannot fear the vagina so much that we fuck it at the sides" invokes intense sexual sensibility. The two most important words in the proverb "vagina" and "fuck" are vulgar words which in the general sense are expected to be avoided or at least substituted with euphemistic forms in a public civil discourse in the modern society, but are used explicitly in the literary discourse of Adelakun. Another example is found in the last proverb in the proverbs listed above. What this points to is that the traditional Yoruba discourse which Adelakun imposes on her English literary discourse does not shy away from invoking sexual imagery in communicative events. 


\subsection{Incantatory Discourse}

Drawing greatly from Yoruba orature, as evidenced in her copious use of Yoruba proverbs, Adelakun further "Yorubanises" her discourse by using Yoruba incantations in her work. According to Olaosun (2011), who cites Oduyoye (1998:203), incantations are powerful or potent speeches or invocations that are used to wrought either positive or negative circumstances on their targets for particular reasons. Ilesanmi (2004) simply describes incantation as Yoruba poetic form that is "mythic and cultic in expectations". The Yoruba world is such with a deep traditional orientation, where there is belief in metaphysical powers. And to invoke such metaphysical powers and forces, it is believed that one must be able to use the appropriate language which is "ofọ", incantation. Therefore, incantation is an integral part of Yoruba discourse since religion and traditional spirituality are synonymous with the Yoruba. As a cultural ambassador, Adelakun reflects this cultural propensity in Under the Brown Rusted Roofs. Below are some incantatory expressions in the text:

- The curse of the okro does not work against the antelope (71)

- It is wàhálà that kills the door; swinging to and fro kills the ẹran òjẹ̀, anybody that took my goat wants wàhálà on his head. (79)

- The bush rat only lifts his hand in vain No one lifts his hands to beat faeces No one lifts his hand to beat urine ... (102)

- Òrúnmìlà àgbonnìrègún, father of Ifá Ifá Olókun who turns problems into joy Front of opón ifá, you can hear Back of opón ifá, you can hear ... (152)

- It is the water lily that tops a river and a man, a woman when they are making children, I will top them all. No matter what, àkàlàmàgbò will still live for a thousand years ... (237)

The above expressions are incantations used by some characters in the text to perform certain spiritual acts such as praying for themselves and protecting themselves against evil forces, wishes and thoughts. The interesting fact about the use of the incantations in the text is that Adelakun does not only use them to nativise her literary discourse but also 
exudes confidence in their potency. For example, on page 102, she presents a scenario where a popular politician in the text Ėrù ò bodò subdues another politician, Chief Olatunbosun, through his metaphysical prowess enacted through incantation. Therefore, one can surmise that Adelakun as a die-hard cultural ambassador commits herself to the projection of the material and non-material aspects in the literary text. The fourth example given above under incantations also betrays the author's intentional projection religion and its discourse in the text. The text is a chant rendered by an Ifa priest, whom a character in the literary text, Lamidi, had taken his son, Mufutau, to for spiritual assistance. Ifa is one of the most popular Yoruba religions practiced within and outside of Nigeria. So, Adelakun exponences this part of Yoruba culture in her work through the reference to the Ife priest and the Ifa incantation produced by the priest.

\subsection{Yoruba Muslim Discourse}

Another discourse pattern used by Adelakun to give a Yoruba colour to her work is Yoruba Muslim discursive style. Religion is popular among the Yoruba who constitute the characters in the text and they are divided along religious lines into Christians, Muslims and Traditionalists. However, as Opeloye (2011) shows, even the Muslim Yorubas still infiltrate their religious practices with Yoruba traditional practices, making them to have multiple identities. Since language is tied to culture (religion inclusive), this multiplicity of identity also manifests in the language of the Yoruba, especially Muslim Yoruba, as there are certain features of Arabic and Islamic discourse which are appropriated in the everyday discourse of Muslim Yorubas. Below are examples of such expressions in the text:

- Ina lillahi wahinali ilahi rojiun (57)

- Barika (114)

- Aliamdulilahi $(114,188,248)$

- Alahuakabar $(123,157)$

- Barika Allahu (138)

- Awusubilahi (190)

The above listed expressions are Arabic expressions typically used by Muslims in different circumstances for the communication of various meanings. However, among the Yoruba Muslims, they are pragmatically appropriated mainly for exclamatory purposes in 
relation to the matter at hand. These kinds of expressions and more often occur in the natural language of many Yoruba Muslims such that they have become popular to the extent that some non-Muslim Yoruba speakers use them. Adelakun thus intentionally gives representation to this discursive style of Yoruba Muslims in her desire to represent the reality of language use among the Yoruba of Ibadan, the setting of her text, and perhaps to reveal the impact of Islam on Yoruba Muslims' language use. While "aliamdulilahi", "Barika Allahu" and "Barika" are used by certain characters in the text to express their instantaneous emotions about certain positive circumstances in the text, "Alahu Akbau" and "Awusubilahi" are used to react to scary and unfortunate circumstances as typical of the Yoruba.

The expression "Inalilahi wahinali ilahi rojiun", which is the natural statement of every Muslim at the mention of the death of any human being, is also used to reflect the religious influence on the language of the Yoruba. To show lucidly that the words have been appropriated into Yoruba discourse, the author gives the forms of the words as used among Yoruba Muslims as different from the standard forms of the words. For example, the word "awusubilahi" is a typical traditional Yoruba variant of "ahusubilahi" common among the non-elite Yoruba Muslims.

\subsection{Traditional Yoruba Advertising Poetry (Ewì İpolówó)}

The author also imbues the literary work with traditional Yoruba identity by employing traditional Yoruba advertising poetry in the work. Poetry is an important aspect of Yoruba orature and language performance which foregrounds both the utilitarian and aesthetic dimensions of language. One feature of Yoruba discourse is traditional advertising poetry (ewi ipolówó). According to Osundare (2002), ewì ipolówó is an indigenous form of advertising among the Yoruba that is done through hawking. Olateju (2009: 157) states that "Just like the modern forms of advertising on the electronic, print and other media, the essence of ipolówó is to bring commodities being advertised to the consciousness and reach of consumers". It is a discourse genre that enriches and transmits Yoruba language and culture to the world. In her cultural romanticism, Adelakun uses advertising poetry (ipolówó) in her debut novel. Below are examples from the text: 
- E ra àkàrà ẹ túko wò. (Buy àkàrà to taste ẹ̀ko.) (85)

- É ra eja, e sebè (Buy fish and cook stew) Eja dé, obè dé. (Fish is here, stew is ready to be made) (10)

The above examples of the traditional Yoruba advertising poetry add to the Yoruba identity projected through the theme, setting and language of the text. Apart from the lyrical quality of the expressions which are foregrounded in the expressions, the regularity of the patterns in the latter example shows that Yoruba discourses also deploy structural parallelism for fictional purposes like discourses in other languages. The similarity of the structure of the two independent clauses and the repetition of "de" which translates to "arrives" or "comes" highlight the stylistics of advertising poetry in traditional Yoruba settings. Through the brief exemplification of advertising poetry in the text, the author gives a Yoruba mark to the text just as she preserves traditional advertising poetry of the Yoruba.

\subsection{Lineage Praise Singing (Oriki)}

An important aspect of Yoruba orature used for the nativisation of Under the Brown Rusted Roofs is the use of lineage praise texts. An important aspect of Yoruba culture is the rendition of family, township and onomastic praise poetry. Such poetic texts whenever rendered edify the Yoruba culture and makes the individuals concerned proud of themselves. Sogunro (2014) describes oriki as Yoruba panegyric poetry which is an important part of the culture and the daily life of the Yoruba, especially the older generations. Adelakun gives her English literary discourse taints of this traditional African and Yoruba poetic performance in order to project Yoruba language and culture. For instance, many times in the text, individuals are praised through lineage praise poetry. Below are instances of such in the text:

- Omo abikan (Scion of Abikan)

Omo așòwò ní wúrà lẹ́rù (One trader who has gold and goods)

Omo t'ori òjè re Idá (One who because of profit goes to Ida)

M'érin ní Mojà (One who captured an elephant in Moja) (15)

- Máa wolè, máa rora (Watch your steps, move gently.)

Omo ajisegirí (The son of Ajísegírí) 
Máa rora (Move gently)

Ekùn ta gìrì gbéra rẹ nijà (The leopard jerks his body to defend himself)

Máa wolè, máa rora (Watch your steps, move gently.)

Agbonragijì, adúró d'ogun (One who shakes himself vigorously and waits for war to advance)

Máa wolè, máa rọa (Watch your steps, move gently.) (224)

In the first example above is a genealogy praise poem which Chief Arigbabuwo's mother, İyá Àgbà, uses to praise a new baby that his daughter-in-law had. The lineage associated with the praise poem is Abíkan which is given in the first line. It is significant that "omọ" (child of) keeps occurring at the beginning of the lines of the lineage poem showing that the individual is consistently being praised in line with his affinity with the lineage. The style also gives some lyrical effect to the text. The lineage praise text features structural parallelism which is also used to confer lyricism and rhythm on the text. This is demonstrated in the lines: One trader who has gold and goods / One who because of profit goes to Idá/ One who captured an elephant in Mojà, which are all nominal groups with the MHQ structure.

The second instance of praise poetry in the text is a personalised one. The Yoruba culture, being one which acknowledges "bigmanism" and celebrates those considered very successful or wielding some influence, allows for the creation and chanting of personalized praise poetry for such personalities. This is the cultural nuance demonstrated by Adelakun in the text as the powerful politician in the setting of the text, simply given as $B a b a$, itself an honorific word, is praised profusely through the oriki. A close look at the text shows that it also contains structural parallelism as the expression: "Watch your steps, move gently" occurs three times in the poem. This enhances the lyricism of the poem, making it sound appealing to the ears. There is also the association of the personality of the Bàbá with that of leopard in the poem, giving the Baba the sterling attributes of a leopard.

There are indeed many other related poetic performances in Adelakun's literary discourse in Under the Brown Rusted Roofs through which she projects certain Yoruba cultural ideations, indexes aspects and features of Yoruba discourse and transposes such features into the English language. For example, there are cultural songs/chants performed at funerals among the Yoruba in the text, there are songs used at social functions in 
contemporary Yoruba society and those used by children while playing with their peers (see pages 53, 54 and 196).

\section{Conclusion}

Literature being an embodiment of the culture and thoughts of a people reflects the realities in human societies and human tendencies. And since language is the purveyor of literature, it also becomes an agent for the distillation of the peculiar cultural, societal and individual tendencies of a people. Abimbola Adelakun has demonstrated in her work a commitment to the deployment of literature for the promotion of her Yoruba cultural identity through the nativisation of the language of her text to bear peculiar lingualcultural features and discursive styles of the Yoruba. She has further demonstrated that, just as many earlier and iconic African literary writers have shown, the language of a literary production is a huge weapon for the glorification and stamping of linguistic and cultural identities, and the sensitisation of the audience to the ideals of lingual-cultural patriotism/nationalism. The author shows that even though there are claims of the erosion of indigenous knowledge among the youth in the Nigerian society, especially in the areas of language and culture, some members of the younger generation are still aware of the potency of their indigenous languages and cultures for their personal, societal and cultural edification. Therefore, using the words of Coker (2013:203), who examined cultural romanticism in Osundare's poetry, Adelakun's debut novel "attests to the viability of the agency of literature for cultural preservation".

It is remarkable that Adelakun does not only employ in her text strategies for nativising the English language that have been established in the literature through considerations of works of writers such as Achebe, Soyinka and Osundare, but also recreates other pertinent features of Nigerian English in the Nigerian society. The elaboration of incantatory language, Yoruba Muslim lexis, traditional Yoruba advertising poetry and lineage poetry mark Adelakun's creation of domesticated English in her work different from earlier samples from writers and scholars earlier mentioned.

To sum up, this study posits that through the deployment of lingual-cultural discourse features such as lexical transfer, literal translation, coinages, code-mixing, proverbs, incantatory discourse, Yoruba Muslim discourse, Yoruba advertising poetry and lineage praise singing, Adelakun renews the English language, creates a vivid Yoruba identity for her literary discourse and presents such identity to the international world. Therefore, one can surmise that while the present inevitability of the use of English for 
Ademilokun: Aspects of Yoruba Lingual-cultural Retentions in Abimbola Adelakun's Under the Brown Rusted Roofs

various purposes in the African world persists, the desire to stamp unique African identities on English language by African writers has not shrunk, as even the new generation of African writers indexes their African identities through their expressive resources. 


\section{References}

Abdullahi-Idiagbon, M. \& Olaniyi, O. (2011). Coinages in Nigerian English: A sociolinguistic perspective. African Nebula 3, 78-85.

Adedoyin, A.A. (2001). "Language of African Literature". In Fakoya A. A. \& Ogunpitan S.A. (Eds.), The English Compendium Vols 3 \& 4 (pp. 212-221). Lagos: Dept. of English, LASU.

Adejare, O. (1992). Language and Style in Soyinka: A Systemic Text Linguistic Study of a Literary Idiolect. Ibadan: Heinemann.

Ayeleru, B. (2011). Linguistic innovation in the new West African Europhone novel: Between interlanguage and indigenization. California Linguistic Notes, XXXVI (1): 1-32.

Ayoola, K.A. (2014). "Things Fall Apart as the Avant Courier of the Nigerian Variety of English". In Anyadike, C. \& Ayoola, K. (Eds.), Blazing the Path: Fifty Years of Things Fall Apart (192-207). Ibadan: HEBN Publishers.

Barbe, K. (1996). The dichotomy of free and literal translation. Meta, XLI (3): 328-337.

Coker, O. \& Ademilokun. (2013). An appraisal of the language question in third-generation African fiction. The African Symposium, 13 (2): 86-93.

Coker, O. (2013). Cultural romanticism in Niyi Osundare's Village Voices. Ife Journal of Languages and Literatures, 1 (1): 195-203.

Essien, O. (1997). The English language and code-mixing: A case study of the phenomenon in Ibibio. In A. Bamgbose, A. Banjo \& A. Thomas (Eds.), New Englishes: A West African Perspective (269-283). Asmara: Africa World Press.

Olaosun, I. (2011). Incantation as discourse: A discourse-stylistic study of the confrontational scene of Ola Rotimi's tragic drama - The Gods Are Not to Blame. In J. Makokha, O. Obiero \& R. West-Pavlov (Eds.), Style and Structure in African Literature: Emerging Perspectives in Fiction, Drama and Orature. New York: Rodopi.

Olateju, A. (2009). Jedi O M'akowe (Hermorrhoid Respects Not Even the Educated Elite): A sociolinguistic-stylistic analysis of the language of Yoruba herbal medicine practitioners. In A. Ojo \& L. Moshi (Eds.), Selected Proceedings of the $39^{\text {th }}$ Annual Conference on African Linguistics. Somerville, MA: Cascadilla proceedings project.

Opeloye, M.O. (2011). The Yoruba Muslims' cultural identity question. Ilorin Journal of Religious Studies, 1 (2): 1-18.

Osundare, N. (2002). The stylistics of ipolowo. Department of English Seminar, University of Ibadan, Ibadan, Nigeria. 
Ademilokun: Aspects of Yoruba Lingual-cultural Retentions in Abimbola Adelakun's Under the Brown Rusted Roofs

Sogunro, B.O. (2014). Yoruba oriki in English: Rhythm analysis of Osundare's 'Harvest Call'. African Research Review, 8 (1): 18-31.

Soyinka, W. (1988). Art, Dialogue and Outrage. New Horn Press.

Syal, P. (1991). Discourse styles and functions in new literatures in English: A reading of Wole Soyinka's "Idanre". ARIEL: A Review of International English Literature, 22 (4): 91-108.

Varga, D., Dvorski, L. \& Bjelobaba, S. (2011) English loanwords in French and Italian daily newspapers. SRAZ LVI, 71-84.

Wali, O. (1963). The dead end of African literature. Transition, 10: 13-15. 